\title{
Appendix: The distribution of the Slavic determiners under investigation
}

This appendix presents the Slavic data (Croatian, Czech, and Russian) on the distribution of the determiners which are investigated in chapter 3. The data is structured concerning the hierarchical order of the different levels on the scale of uniqueness. The data have been provided by native speakers of the corresponding languages. A list of my informants for each language is given in the introduction.

\section{Croatian}

\section{Anaphoric SNs:}

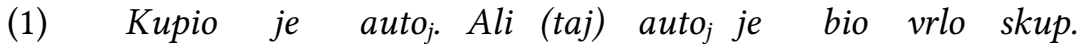
buy.PST AUX car but DEM car AUX was very expensive 'He bought a car. But the car was very expensive.'

(2) Novoga smo psa kupili prošle godine. (Taj) pas je new AUX dog buy.PST last year DEM dog COP veoma umiljat.

very sweet

'We bought a new dog last year. The dog is very sweet.'

(3) Moj prijatelj je kupio zanimljivu knjigu $u_{j}$ my friend AUX buy.PST interesting book about životinjama. Rekao je da (ta) knjiga $a_{j}$ nije bila animals say.PST AUX that DEM book NEG was skupa. expensive 'My friend bought an interesting book about animals. He said that the book was not expensive.' 
In (4), there is interspeaker variation concerning the use of the demonstrative $t u$. Some prefer it while others regard it as optional.

(4) Prošle sam godine na konferenciji u Španjolskoj upoznao last AUX year on conference in Spain meet.PST jednu ženu $u_{j}$. Dvije godine kasnije, dok sam bio na one woman two years later while AUX was on praznicima u Njemačkoj, sreo sam tu/(tu) ženu holiday in Germany meet.PST AUX DEM woman again 'Last year I met a woman at a conference in Spain. Two years later while I was on holiday in Germany, I met the woman again.'

(5) U jedan je sat neki čovjek ušao u sobu. Kad at one AUX o'clock some man enter.PST in room when sam ja ušao u 1:15 (taj) čovjek je stajao kraj AUX I enter.PST at 1:15 DEM man AUX stand.PST next_to prozora.

window

'At one o'clock a man entered the room. When I entered at 1:15, the man was standing next to the window.'

(6) U jedan je sat neki čovjek ušao u sobu. Kad at one AUX o'clock some man enter.PST in room when sam ja ušao u $1: 15 \mathrm{kraj}$ prozora je stajao taj AUX I enter.PST at 1:15 next_to window AUX stand.PST DEM čovjek . $_{\text {. }}$

man

'At one o'clock a man entered the room. When I entered at 1:15, the man was standing next to the window.'

SNs with complements establishing uniqueness:

(7) Kako se zove (ona) ptica koja krade? how REFL call.3SG DEM.DIST bird REL steal.3SG 'What is the name of the bird that steals?' 
(8) (Ona) žena koju sam jučer vidio bila je lijepa.

DEM.DIST woman REL AUX yesterday saw was AUX beautiful 'The woman I saw yesterday was beautiful.'

(9) (Onaj) čovjek koji je izumio telefon dobio je

DEM.DIST man REL AUX invent.PST telephone got AUX

Nobelovu nagradu.

Nobel Prize

'The man who invented the telephone was awarded the Nobel Prize.'

\section{Definite associative anaphors:}

According to my Croatian informants, no determiners occur with definite associative anaphors or the other contexts of the scale that follow.

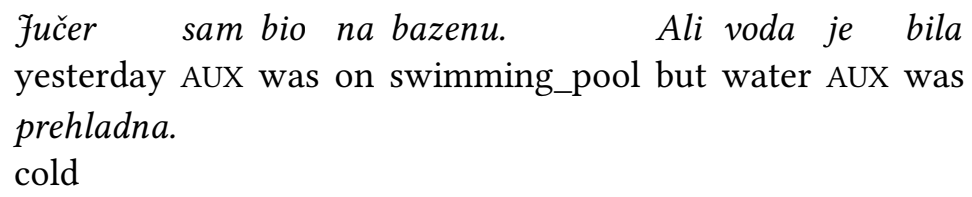

'I was in the swimming pool yesterday. But he water was too cold.'

(11) Kupili smo star auto $i$ motor je stalno have-1PL.PRS we old car and engine COP constantly pokvaren.

broken

'We bought an old car and the engine is constantly broken.'

(12) Imam lijepu šalicu Ali ručka joj je otpala. have.1SG.PRS nice cup but handle POSS.PRON COP broken 'I have a nice cup, but the handle is broken.'

(13) Jučer sam bio u kinu, $i$ film je bio dosadan. yesterday AUX was at cinema and film AUX was boring 'I went to the cinema yesterday and the film was boring.' 


$$
\text { Nakon kina razgovarali smo o filmu. }
$$
after cinema.GEN talk.PST AUX about film.

Dopali su nam se glumci.

like.PST AUX us REFL actor.PL

'After the cinema we talked about the film. We liked the actors.'

(15) Kad sam ušao u autobus pitao sam vozača when AUX enter.PST in bus ask.PST AUX driver koliko stoji karta. how_much cost.3SG ticket

'When I got into the bus, I asked the driver how much a ticket costs.'

(16) Prošli smo tjedan bili na vjenčanju našega susjeda. last AUX week were on wedding our.GEN neighbour.GEN Mlada je bila prelijepa. bride AUX COP beautiful 'Last week we were at our neighbour's wedding. The bride was beautiful.'

(17) Kad je fan ušao u crkvu obred je već bio when AUX Jan enter.PST in church service AUX already was počeo. Svećenik je molio Očenaš. start.PST priest AUX pray.PST Lord's Prayer 'When Jan entered the church, the service had already started. The priest was saying the Lord's Prayer.'

(18) U subotu sam bio $u$ francuskom restoranu. Hrana mi se in Saturday AUX was in French restaurant food me REFL jako svidjela. very like.PST 'I was in a French restaurant on Saturday. I liked the food a lot.' 
(19) Nako što su vidjeli stan htjeli su razgovarati s after that AUX seen flat want.PST AUX talk with vlasnikom o cijeni. owner about price.

'After seeing the flat, they wanted to talk with the owner about the price.'

(20)

$$
\text { Dok smo stajali pred Empire State Building }
$$
while AUX stand.PST in_front_of E.S.B.

visina joj je bila dojmljiva.

height POSS.PRON AUX was impressive

'When we stood in front of the Empire State Building, the height was impressive.'

\section{Complex ICs:}

(21) Živim u najljepšem gradu u zemlji. live.1SG in most_beautiful city in country 'I'm living in the most beautiful city in the country.'

(22) Knjiga se nalazi u drugoj ladici. book REFL lie.3SG in second drawer 'The book lies in the second drawer.'

(23) Moram sići na sljedećoj stanici. must.1SG get_off on next stop 'I have to get off at the next stop.'

(24) Posljednji je student otišao kući. last AUX student went home 'The last student went home.'

\section{Lexical INs/FNs:}

(25) Sunce sja.

sun shine.3SG.PRS

'The sun is shining.' 
(26) Ovo je kraj filma

DEM COP end film

'This is the end of the film.'

(27) Udaljenost između Španjolske i Njemačke iznosi

distance between Spain and Germany amount.3SG

oko $2000 \mathrm{~km}$.

about $2000 \mathrm{~km}$

'The distance between Spain and Germany is about 2000 km.'

(28) Papa je poglavar katoličke crkve.

Pope COP head Catholic church.GEN

'The Pope is the head of the Catholic Church.'

\section{Czech}

\section{Deictic SNs:}

(29) To(hle) auto je hezké.

DEM car COP nice

'This car is nice.'

\section{Anaphoric SNs:}

My Czech informants prefer the demonstrative ten with anaphoric SNs. However, ten is not considered as obligatory.

(30) Jan si včera koupil knih-uj. Když začal čist, Jan REFL yesterday buy.PST book-ACC when begin.PST read vsiml si, že už tu knih-uj četl. notice.PST REFL that already DEM book-ACC read.PST 'Jan bought a book yesterday. When he began to read it he noticed that he had already read this book.'

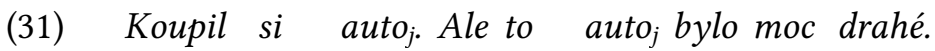
buy.PST REFL car but DEM car was very expensive 'He bought a car. But the car was very expensive.' 
Byl jednou jeden král $l_{j}$ a ten král $l_{j}$ měl tři was once one king and DEM king have.PST three dcery. ${ }^{1}$

daughter.PL

'Once upon a time, there was a king and the king had three daughters.'

(33) Pozoroval jsem, jak do pokoje vešel mužj. Když jsem do observe.PST AUX how in room enter.PST man when AUX in

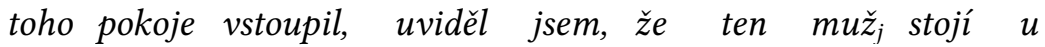
DEM room enter.PST see.PST AUX that DEM man stand at okna.

window

'I observed a man going into the room. When I entered, I saw that the man was standing at the window.'

\section{SNs with complements establishing uniqueness:}

In (35) and (36), there is interspeaker variation with respect to the optional and preferred use of ten. In all other examples of complements establishing uniqueness, the demonstrative is preferred (34), (37) or optional (38) and (39).

$$
\text { Znáte, doufám, toho učitele, co má chatu a auto? }
$$
know hope.1SG DEM teacher REL have.3SG house and car 'You know, I hope, the teacher who has a weekend house and a car?'

(35) To je na tom/(tom) gauči, co na nĕm spi.

DEM COP on DEM couch REL on it sleep.3SG.PRS

'This is on the couch on which he is sleeping.' 
(36) To je ten/(ten) človĕk, o kterém jsme mluvili. ${ }^{4}$ DEM COP DEM man about REL AUX talk.PST 'This is the man we talked about.'

(37) Ta žena, kterou jsem včera viděl, byla hezká. DEM woman REL AUX yesterday see.PST was beautiful 'The woman I saw yesterday was beautiful.'

(38) Jak se jmenuje (ten) pták, který krade? how REFL call.3SG DEM bird REL steal.3SG 'What is the name of the bird that steals?'

(39) Nobelovu cenu získal (ten) muž, který vynalezl telefon. Nobel Prize get.PST DEM man REL invent.PST telephone 'The man who invented the telephone was awarded the Nobel Prize.'

\section{Definite associative anaphors:}

(40) Včera jsem byla na plovárně, ale voda byla yesterday AUX was on baths but water COP studená.

cold

'I was in the swimming baths yesterday. But the water was cold.'

(41) Mám hezký hrnek, ale jeho ucho je have.1SG.PRS nice cup but POSS.PRON handle COP ulomené. broken 'I have a nice cup, but the handle is broken.'

$\overline{4}$ This example is taken from Berger (1993: 148). 
(42) Máme staré auto. Proto je jeho motor pořád have.3PL old car therefore COP POSS.PRON engine always pokažený.

broken

'We have an old car. Therefore, the engine is always broken.'

(43) Včera jsem byla $v$ kině, ale (ten) film byl nudný. yesterday AUX was in cinema but DEM film was boring 'I went to the cinema yesterday. But the film was boring.'

(44) Když jsem nastoupil do autobusu, zeptal jsem se when AUX get.PST in bus ask.PST AUX REFL ridiče, kolik stojí jizdenka.

driver how much cost ticket 'When I got into the bus, I asked the driver how much a ticket costs.'

(45) Po kině se ještě bavili o (tom) filmu. after cinema REFL still talk.PST about DEM film (Ti) herci se jim líbili. DEM actor.PL REFL them please.PST 'After the cinema we talked about the film. We liked the actors.'

(46) Minulý týden jsme byli na svatbě mého souseda. last week AUX were on wedding my.GEN neighbor.GEN (Ta)/Ø nevěsta byla prekrásná.

DEM bride was beautiful

'Last week we were at our neighbour's wedding. The bride was beautiful.'

(47) Když jsme stáli před Empire State Building, when AUX stood in_front_of Empire State Building jeho velikost nás ohromila. POSS height us stunned 'When we stood in front of the Empire State Building, its height stunned us.' 
Když prišel fan do kostela, mše už začala. when came Jan to church service already start.PST Kněz právě predríkával otčenáš. priest just said Lord's Prayer 'When Jan came to the church the service had already started. The priest was saying the Lord's Prayer.'

(49) Poté, co si prohlédla byt, chtěla after that what REFL inspect.PST flat want.PST $s \quad$ majitelem mluvit o cené. with owner talk about price 'After seeing the flat, she wanted to talk with the owner about the price.'

(50) $V$ sobotu jsem byl ve francouzské restauraci. (To) jídlo in Saturday AUX was in French restaurant DEM food mi moc chutnalo.

me very tasted

'I was in a French restaurant on Saturday. I liked the food a lot.'

\section{Complex ICs:}

With complex ICs, the demonstrative ten can appear, which leads to an indication of emotional involvement.

(51) Bydlím $\quad v$ (tom) nejkrásnějším městě $v$ zemi. live.1SG.PRS in DEM SPL.beautiful city in world 'I live in the most beautiful city.'

(52) Kniha leží $\quad v$ (tom) druhém šuplíku. book lie.3SG in DEM second drawer 'The book lies in the second drawer.'

(53) (Ty) poslední holky šly domů. DEM last girl.PL went home 'The last girls went home.' 
(54) Na (té) prišstí zastávce musím vystoupit. on DEM next stop must.1SG get_off 'I have to get off at the next stop.'
Máme
na skladĕ
(ty) nejnovějši vzorky. ${ }^{5}$ have.3PL.PRS on warehouse DEM SPL.late sample.PL 'We have the latest samples in stock.'

(56) Přičemž otevřenost, nezakrývání nepř́iemných věcí with openness non-concealment unpleasant things $a$ hraní $s$ otevřenými kartami je (tou) nejlepši and playing with open cards COP DEM best strategii. ${ }^{6}$ strategy

'With openness, the non-concealment of unpleasant things and playing with open cards are the best strategy.'

\section{Lexical INs/FNs:}

(57) Papež je hlavou církve.

Pope COP head church.GEN

'The Pope is the head of the church.'

(58) To je konec (toho) filmu.

DEM COP end DEM film.GEN

'This is the end of the film.'

(59) Vzdálenost ze Španělska do Německa je 2000 km. distance from Spain to Germany COP $2000 \mathrm{~km}$ 'The distance from Spain to Germany is $2000 \mathrm{~km}$.'

(60) Slunce svití.

sun shine.3SG.PRS

'The sun is shining.'

Taken from Zubatý (1916, quoted after Krámský 1972: 188). The example has slightly been modified in that the demonstrative is put in brackets in order to indicate its optionality.

Taken from Berger (1993: 404). 


\section{Russian}

\section{Anaphoric SNs:}

(61) On kupil mašin- $u_{j}$, no (èta) mašina $a_{j}$ byla očen' he bought car-ACC but DEM car was very dorogoj. expensive 'He bought a car, but the car was very expensive.'

(62) Pered domom naxoditcja mašina. Ja uže in_front_of house.INS be.3SG.PRS car I already včera videl ètu mašin-uj. yesterday saw DEM car-ACC

'There is a car in front of the house. I already saw the car yesterday.'

(63) Ivan uvidel ženščin- $u_{j} . \quad$ (Èta) ženščina $a_{j}$ byla prekrasna. Ivan see.PST woman-ACC DEM woman was beautiful 'Ivan saw a woman. The woman was beautiful.'

\section{SNs with complements establishing uniqueness:}

(64) Kak nazyvaetsja ptica, kotoraja voru-et? how be_called.3SG.PRS DEM.DIST bird REL steal-3SG.PRS 'What is the name of the bird that steals.'

(65) (Ta) ženščina, kotoruju ja u-vide-l včera, byla DEM.DIST woman REL I U-see-PST yesterday was očen' krasivaja. very beautiful 'The woman I saw yesterday was beautiful.' 


\section{Definite associative anaphors:}

According to my Russian informants, no determiners occur with definite associative anaphors or the other contexts of the scale that follow.

$$
\text { U menja est' krasivaja čaška, no (eё) ručka }
$$

at me is nice cup but POSS.PRON handle

slomana.

broken

'I have a nice cup, but the handle is broken.'

$$
\text { My kupi-li star-uju mašin-u, poetomu (eё) motor }
$$

we buy-PST.PL old-ACC car-ACC therefore POSS.PRON engine lomaetsja.

get_broken.3SG.PRS

'We bought an old car. Therefore, the engine is constantly broken.'

(68) Včera ja xodi-l $v$ baccejn, no voda byla očen' yesterday I go-PST to swimming_pool but water was very xolodnoj.

cold

'I was in the swimming pool yesterday. But the water was too cold.'

(69) My včera xodi-li $v$ kino, no fil'm byl skučnym. we yesterday go-PST.PL to cinema but film was boring 'We went to the cinema yesterday. But the film was boring.'

(70) Posle kino my govorili o fil'me. after cinema we talk.PST about film.

Nam ponravilis' aktery.

us please.PST actor.PL

'After the cinema we talked about the film. We liked the actors.' 
(71) Kogda ja zašel $\quad v$ avtobus, ja sprosil voditelja when I enter.PST in bus I ask.PST driver skol'ko stoit bilet. how_much cost.3SG ticket 'When I got into the bus, I asked the driver how much a ticket costs.'

(72) Na prošloj nedele my byli na cvad'be našego on last week we were on wedding our.GEN soseda. Nevesta byla krasivaja. neighbour.GEN bride COP beautiful 'Last week we were at our neighbour's wedding. The bride was beautiful.'

(73) Kogda Džan zašel $\quad v$ cerkov' služba uže načalas'. when Jan enter.PST in church service already start.PST Svjaščennik čital molitvu. priest read.PST prayer 'When Jan entered the church, the service had already started. The priest was saying a prayer.'

(74) Ja byl vo francuzskom restorane $v$ subbotu. Eda mne I was in French restaurant in Saturday food me očen' ponravilas'. very taste.PST 'I was in a French restaurant on Saturday. I liked the food a lot.'

(75) Posle osmotra kvartiry oni xoteli pogovorit's after seeing flat they want.PST talk with xozjainom o cene. owner about price 'After seeing the flat, they wanted to talk with the owner about the price.' 
(76)

Kogda my stojali pered Empire State Building when we stand.PST in_front_of E.S.B

ego vysota vpečatljala.

POSS.PRON height impressive

'When we stood in front of the Empire State Building, the height was impressive.'

\section{Complex ICs:}

(77) Mne nužno vyjti na sledujuščej ostanovke.

me must get_off at next stop

'I have to get off at the next stop.'

(78) Dve poslednie devočki pošli domoj.

two last girl.PL went home

'The last two girls went home.'

(79) Kniga lež-it vo vtorom jaščike.

book lie-3SG.PRS in second drawer

'The book lies in the second drawer.'

\section{Lexical INs/FNs:}

(80) Èto byl konec (ètogo) fil'ma.

DEM COP end DEM film

'This is the end of the film.'

(81) Rasstojanie meždu Germaniej i Rossiej...

distance between Germany and Russia

'The distance between Germany and Russia...'

(82) Solnce svet-it.

sun shine-3SG.PRS

'The sun is shining.' 
